\title{
Studies on Homalomeneae (Araceae) of Borneo VII: Homalomena debilicrista, a new species from Malaysian Borneo, and observations of its pollination mechanics
}

\author{
By Hoe Yin Chen, Wong Sin Yeng, Peter C. Boyce, Wong Mui Hung and \\ Margaret Chan Kit Yok
}

With 2 figures

\begin{abstract}
Hoe, Y.C., Wong, S.Y., Boyce, P.C., Wong, M.H. \& Chan, M.K.Y.: Studies on Homalomeneae (Araceae) of Borneo VII: Homalomena debilicrista, a new species from Malaysian Borneo, and observations of its pollination mechanics. — Plant Div. Evol. 129: 77-87. 2011. — ISSN 1869-6155.

Homalomena debilicrista Y.C.Hoe is described and illustrated as a species new to science from the Matang massif sandstone formation, Kuching Division, NW Sarawak, Malaysian Borneo. It represents the sixth species of the informal Hanneae Complex, a morphotaxon apparently endemic to Borneo and composed wholly of nomenclaturally novel species. Inflorescence events, notably spathe movement mechanisms, and interactions with insect visitors were observed and recorded to determine pollinator/s as part of an on-going programme accumulating data on pollinator guild niche partitioning in Homalomena. Six insect taxa visited the inflorescences during anthesis: (1) Coleoptera Chrysomelidae (Chaloenus schawalleri), Scarabaeidae: Rutelinae (Parastasia bimaculata), Nitidulidae (genus undetermined), and Staphylinidae (genus undetermined) - and (2) Diptera, two species of Colocasiomyia (Drosophilidae). Empirical data strongly implicate P. bimaculata and possibly C. schawalleri to be the pollinators of Homalomena debilicrista. A key to the so-far described species of the Homalomena Hanneae Complex is presented, and the new species is illustrated.
\end{abstract}

Keywords: Araceae, Homalomena, Borneo, Sarawak, Malaysia, pollination, Coleoptera, Chrysomelidae, Scarabaeidae, Chaloenus schawalleri, Parastasia bimaculata.

\section{Introduction}

Pollination mechanisms of Asian Homalomena Schott remain rather poorly documented. Entomological studies by Okada (1986), Yafuso \& Okada (1990), and Sultana et al. (2002) reported brood-site association of various Colocasiomyia (Diptera: Drosophilidae) species with inflorescences of, among others, Homalomena insignis N.E.Br.

Received October 22, 2010, accepted November 12, 2010 
(C. nigricauda), H. lancifolia Hook.f. (C. baechllii, C. bogneri - both reported as Drosophilella), H. pendula (B1.) Bakh.f. (C. heterodonta, C. xanthogaster), and 'H. sagittifolia Schott' (C. nigricauda), but produced no compelling evidence of Colocasiomyia pollination activity.

Mori \& Okada (2001) reported Colocasiomyia (species undetermined) to be the pollinator of Furtadoa sumatrensis M.Hotta since although the inflorescences were also visited by Chaloenus oculatus (Coleoptera: Chrysomelidae) the visitations were too few to justify $C$. oculatus being the pollinator. Furthermore Mori \& Okada (2001) considered $C$. oculatus as a plunderer rather than a pollinator since the beetles damaged the staminate part of the spadix while they ignored the 'reward' offered by the interpistillar staminodes.

Beetle pollination has been reported by Kumano \& Yamaoka (2006) for Homalomena with Parastasia bimaculata (Scarabaeidae: Rutelinae) and Chaloenus schawalleri (Chrysomelidae) pollinating an undescribed Homalomena (erroneously called Homalomena propinqua $\mathrm{Schott}=$ H. rostrata Griff. - see Wong et al., in press). Interpistillar staminodes reported as food-reward structures were consumed by Parastasia bimaculata and C. schawalleri, while Calocasiomyia, which also visited the inflorescences, did not consume these, suggesting $P$. bimaculata and $C$. schawalleri to be the pollinators. Further investigation by Kumano-Nomura \& Yamaoka (2009) revealed P. bimaculata to be a more reliable pollinator than C. schawalleri. The efficacy of P. bimaculata as a pollinator for Homalomena has been reinforced by Tung et al. (2010) in studies of Homalomena giamensis L.S.Tung, S.Y.Wong \& P.C.Boyce. The observations presented here yet further reinforce that beetles, rather than flies, are the primary pollinators for Homalomena.

Homalomena debilicrista Y.C.Hoe, spec. nova - Fig. 1, 2.

Homalomenae josephii proxima, foliis conspicue inter nervos laterales primarios pulvinatis, stipite longiore (ad $19 \mathrm{~mm}$ longo contra $3.5 \mathrm{~mm}$ ), zona florum pistillatorum longiore (ad $4.5 \mathrm{~cm}$ longa contra $2 \mathrm{~cm}$ ) facile distinguenda.

Type: Malaysia, Sarawak, Kuching Division, Matang, trail to Maha Mariamman Indian Temple, $01^{\circ} 35^{\prime}$ ' 25.7” N, 110 13' 12.8'E, 5 June 2010, Hoe Yin Chen AR- 3057 (holotype SAR).

Medium-sized, moderately robust, evergreen, glabrous, strongly aromatic (pungent lime) herbs to ca $95 \mathrm{~cm}$ tall. Stem erect to ascending, ca 3-4 cm thick, green, modules pleionanthic, older parts turning pale brown with conspicuous adventitious roots, these often penetrating the petiole bases; internodes to ca $1.7 \mathrm{~cm}$ long. Leaves 5-17 together; petiole 60-85 cm long $\times 9-12 \mathrm{~mm}$ wide at mid-point, erect to spreading, petiole bases clasping, generally red, although occasionally individuals with green petiolar bases occur, adaxially slightly grooved, petiole weakly pulvinate ca $1 / 4$ to $1 / 2$ way from leaf blade insertion, green, occasionally pale red, always with faint, scattered pale green to rarely dirty white longitudinal broken ridges; petiolar sheath $25-30 \mathrm{~cm}$ long, ca $1 / 3$ of petiole length, red, very rarely green, wings up to $1 \mathrm{~cm}$ wide, open, rounded and weak- 


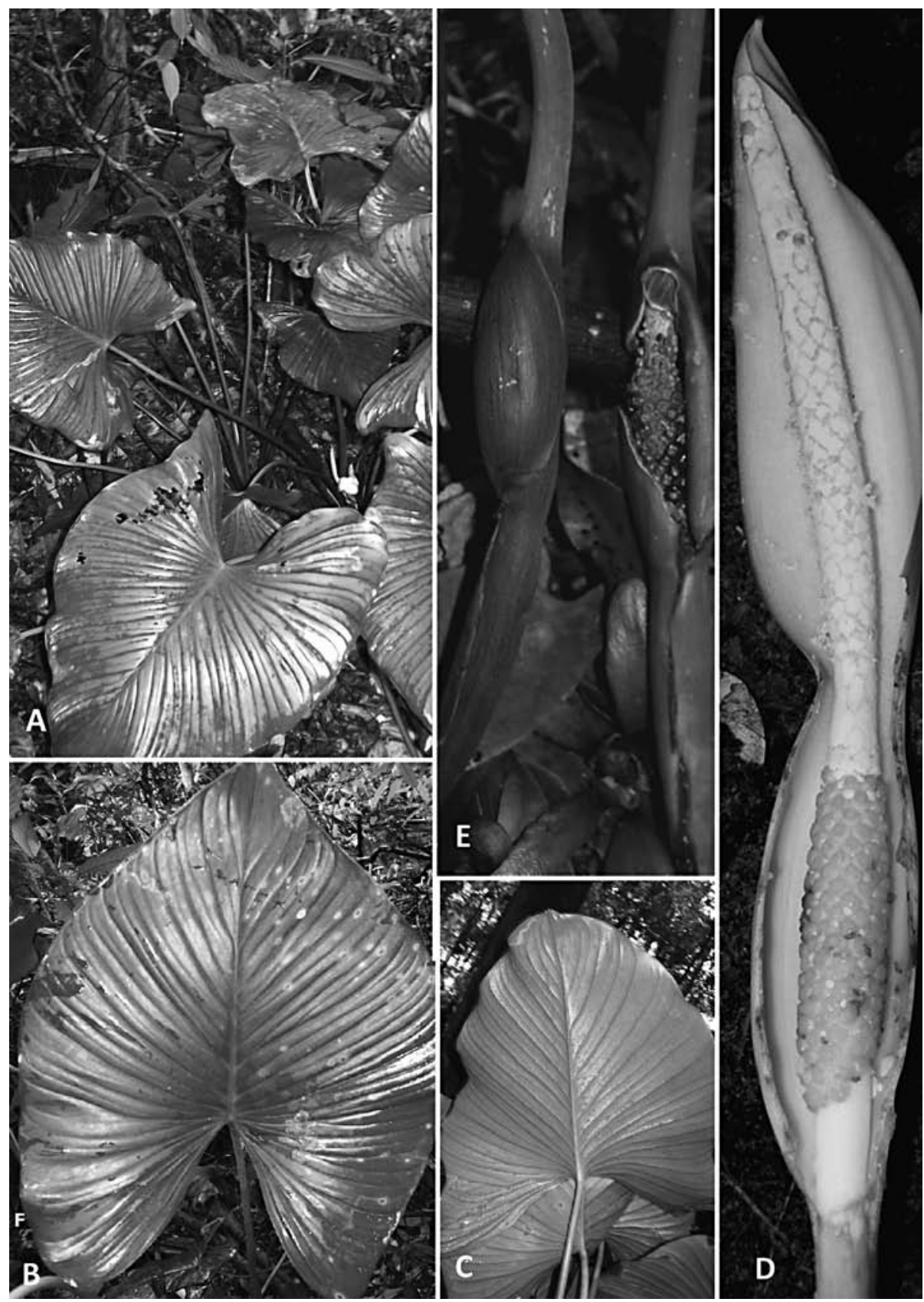

Fig 1. Homalomena debilicrista. A. Plants in type habitat; B. Leaf blade, abaxial surface. Note the distinctive quilting of the blade tissue between the primary veins; C. Leaf blade, abaxial surface; D. Inflorescence at late staminate anthesis, the lower spathe has been articicially removed. Note the resin droplets remaining on the distal portion of the spadix, and the remnants of pollen strings towards the middle part; E. Infructescences. Note that the persistent spathe has turned dark red. The right hand spathe has been opened artificially to show the nearly ripe dark red fruits. 


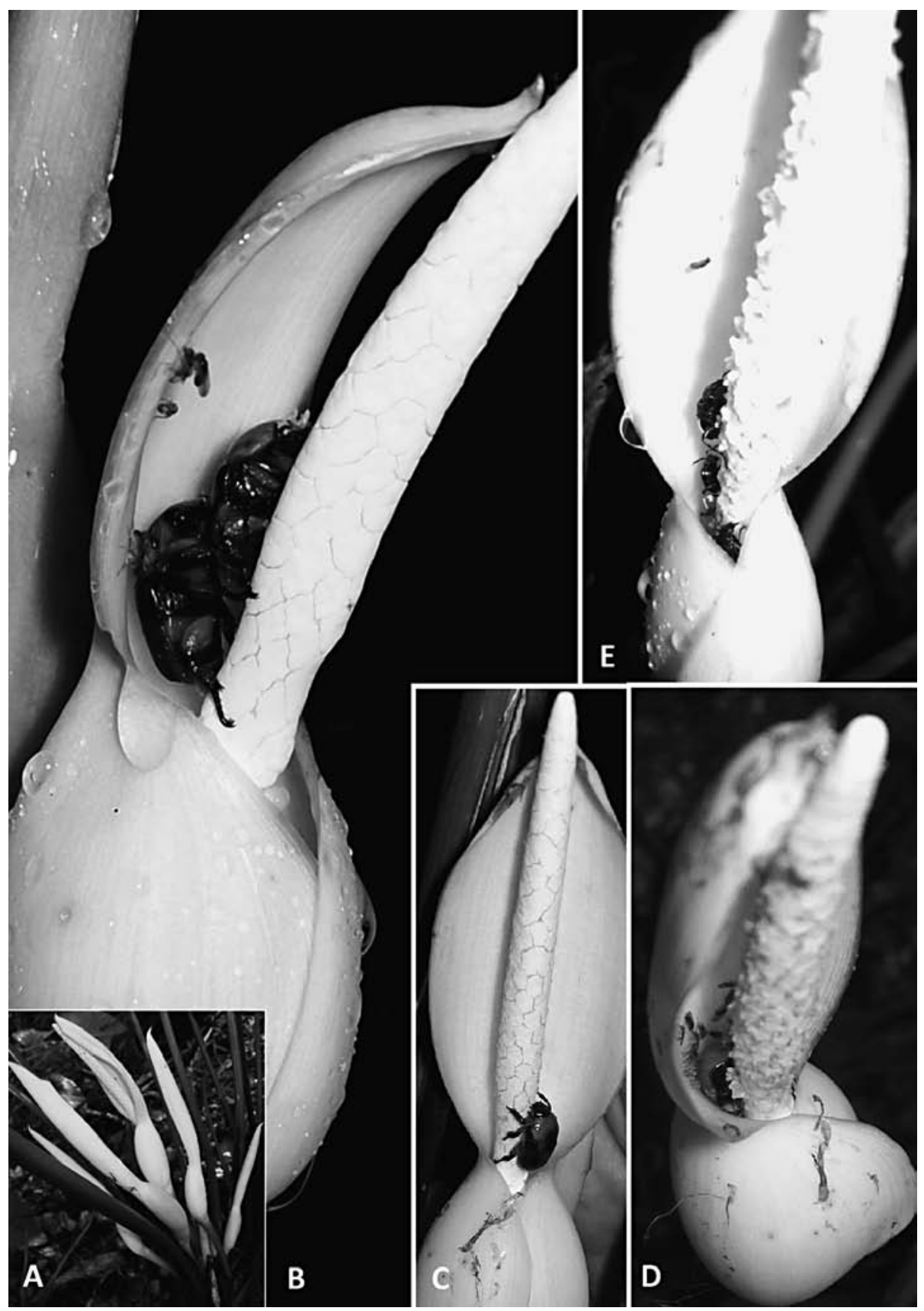

Fig 2. Homalomena debilicrista. A. Flowering plant. The middle inflorescence is at pistillate anthesis, the one immediately to the left is post anthesis and beginning to turn pink; B. Parastasia bimaculata mating at the lower part of the staminate zone; note the Colocasiomyia flies mating on the interior of spathe limb; C. Inflorescence approaching staminate anthesis with yellowish green resin exuding from between the staminate flowers; D Inflorescence at staminate anthesis with Parastasia bimaculata on the lower part of the staminate zone. Note the poll;en strings and masses of sticky pollen/resin mixture; E. Chaleonus schawalleri on staminate flower zone during staminate anthesis. 
ly decurrent at apex, margins slightly incurved, tapering to apex, sheath initially persistent, soon marcescent along the margin, eventually whole sheath marcescent; leaf blade broadly ovato-sagittate or ovato-cordate, $31-40 \mathrm{~cm}$ long $\times 24-33 \mathrm{~cm}$ wide, thinly leathery, conspicuously quilted between the primary lateral veins, with conspicuous (notably on newest leaves) areolate-punctate glands (? extrafloral nectaries) present on the leaf blade, blade semi-glossy medium green adaxially, paler abaxially, drying uniformly pale yellow, base cordate or sagittate, posterior lobes spreading, subtriangular, 11-19 cm long, tip obtuse, short-cuspidate for ca $1 \mathrm{~cm}$ or short-acuminate for $\mathrm{ca} 2 \mathrm{~cm}$, apiculate with a hook-like black or red mucro to ca $4 \mathrm{~mm}$ long; midrib raised abaxially, ca $6 \mathrm{~mm}$ wide at the base, $4 \mathrm{~mm}$ wide at the centre, adaxially flush with blade, ca $5 \mathrm{~mm}$ at the base, $3 \mathrm{~mm}$ at the centre; 15-16 primary lateral veins on each side, diverging at $40^{\circ}-90^{\circ}$ from the midrib, adaxially impressed, abaxially raised, curved sharply towards the apex when near the margin; interprimary veins impressed, almost the same as the primary lateral veins, alternating irregularly with primaries, posterior lobes each with 3-4 primary lateral veins; secondary venation rather obscure, raised on both surfaces; tertiary venation not visible, all veins running into a thickened intermarginal vein. Inflorescences 1-6 together in a gorgonoid synflorescence, erect, the first inflorescence in a flowering module subtended by a foliage leaf, each subsequent inflorescence subtended by a 2-keeled 5-7 $\mathrm{cm}$ pale brown, rarely pale pink prophyll; peduncle 15-19 cm long $\times$ ca $5.2 \mathrm{~mm}$ wide, matte, pale green or sometimes yellowish distally, shading to pale pink, with dirty white obscure longitudinal broken ridges as for petiole. Spathe white with red tip and mucro, early on with the middle portion around the constriction pale green, turning pale pink after anthesis, up to $12 \mathrm{~cm}$ long; lower spathe ovoid-ellipsoid, ca $4 \mathrm{~cm}$ long $\times 3 \mathrm{~cm}$ wide at pistillate anthesis, constricted at the junction of the spathe limb coinciding with the lower-most fertile staminate flowers; spathe limb ca $6.5 \mathrm{~cm}$ long $\times 2.6 \mathrm{~cm}$ wide at pistillate anthesis, ovato-triangular, mucro to ca $4 \mathrm{~mm}$, lower spathe limb loosening and then opening wide at pistillate anthesis, spathe limb slightly furled at staminate anthesis. Spadix exceeding spathe by the time of staminate anthesis, ca $13 \mathrm{~cm}$ long post staminate anthesis, slender-fusiform, narrowing in the lower part of staminate zone coinciding with the constriction of the spathe; stipe 6-19 mm long $\times 5-7 \mathrm{~mm}$ width, weakly somewhat fusiform-cylindric, inserted slightly obliquely on peduncle, glossy white; pistillate zone $4.5-3.4 \mathrm{~cm}$ long $\times 9.5 \mathrm{~mm}$ wide, ca $1 / 3$ length of spadix weakly fusiform; pistils weakly polygonal-cylindrical, densely arranged when fresh, $1.25-1.5 \mathrm{~mm}$ in diam., $1.2 \mathrm{~mm}$ tall, yellowish, turning dark brown or grey in alcohol, stigmatic exuding pale brownish grey in alcohol, to almost cover the whole pistillate zone; each pistil associated with 2-4 interpistillar staminodes, these stipitate, equalling the associated pistils, tip abruptly globose, ca $0.7 \mathrm{~mm}$ in diam., waxy white, staining very pale brown in alcohol; style barely differentiated; stigma truncate and smaller than ovary, globose-capitate, conspicuously wet at female anthesis, very pale grey when fresh, staining grey or rarely dark brown in alcohol; interstice staminodes rounded or irregularly polygonal, each comprising a single sterile anther, $0.9-1.2 \mathrm{~cm}$ long $\times 6 \mathrm{~mm}$ wide, ca $2 \mathrm{~mm}$ in diam., waxy white; staminate zone $11.2 \mathrm{~cm}$ long $\times 7.2 \mathrm{~mm}$ wide, ca $2 / 3$ length of spadix, lower part slightly constricted, white with yellowish-green resin produced from between the staminate flowers at the onset of staminate anthesis; staminate flowers irregularly polygonal, each comprising 
4-6 truncate stamens, overtopped by a large flat synconnective, ca $2.5 \mathrm{~mm}$ diameter, white, turning pale brown in alcohol, terminal-most flowers on spadix often seemingly sterile. Infructescences exceptionally up to 28 together, but usually fewer, declinate; peduncle matte pale pink occasionally somewhat yellowish or greenish at the base, with dirty white longitudinal broken ridges; fruiting spathe entirely persistent, turning deep red, lower spathe ca $7 \mathrm{~cm}$ long $\times$ ca $2.2 \mathrm{~cm}$ wide, ultimately splitting upwards from base to reveal the ripe fruits; spathe limb ca $6.1 \mathrm{~cm}$ length $\times \mathrm{ca} 1 \mathrm{~cm}$ wide; fruits ca $4 \times$ larger than ovaries prior to pollination, $2.7-8.3 \mathrm{~mm} \times 1.5-3.8 \mathrm{~mm}$ wide, medium green, ripening red, smelling lime when crushed; stigma impressed, ca 1.2 in diameter, rounded, orange brown, unpollinated ovaries noticeable shrunken with 3-4 pores on the stigma; stipe pale yellow white; staminate portion of spadix turned brown with all spent flowers degrading into a viscous liquid, smelling of fermenting sour plum; seeds not observed.

Distribution: Malaysian Borneo, Sarawak. Known only from the type locality, where it is common.

Ecology: Gentle to steep slopes in lowland tropical perhumid forest on red ultisols, often beside small streams and along somewhat open trail margins. $250-375 \mathrm{~m}$ asl.

Etymology: From the Latin debilis — weak, and crista — a crest, in allusion to the diagnostic longitudinally weakly-crested petioles and peduncles.

Homalomena debilicrista belongs to the Hanneae complex (Cyrtocladon Supergroup, see Boyce \& Wong, 2008; Ng et al, in press) defined by thinly leathery, semi-glossy cordato-sagitatte leaf blades with scattered adaxial areolate-punctate glands, red petiolar sheaths, the spathe limb length exceeding that of the lower spathe, a staminate flower zone producing resin droplets at staminate anthesis, and the spathe turning pink during anthesis and red into fruiting. Homalomena debilicrista is distinguished by the raised, broken whitish striae on the petiole and peduncle, the petiolar sheath eventually fully marcescent, and the white pistils.

Recognition and description of $H$. debilicrista takes to six the number species that have been formally described for the Hanneae complex.

They may be keyed out as follows:

1. Petioles green or reddish, with inconspicuous longitudinal pale striae . . . . . . 2

- Petiole proximally green, distally white with very conspicuous prominently raised glossy cherry-red ridges. Leaf blade abaxially glaucous. Mulu (Sarawak), shales

. . . . . . . . . . Homalomena striatieopetiolata P.C.Boyce \& S.Y.Wong

2. Pistillate flower zone abruptly wider than staminate flower zone; pistils pale orange. Batang Ai (Sarawak) and N part of Ulu Sungai Kapuas (Kalimantan Timur), sandstones . . . . . . . . . . . . . . H. hanneae P.C.Boyce \& S.Y.Wong

- Pistillate flower zone imperceptibly merging with, or slightly narrower than, staminate flower zone; pistils not pale orange . . . . . . . . . . . . . . 3

3. Pistillate flowers green. Batang Ai (Sarawak), sandstones . . . . . . . . . . . . . . . . . . . . . . . . H. sengkenyang P.C.Boyce \& S.Y.Wong

- Pistillate flowers white or yellowish . . . . . . . . . . . . . . 4 
4. Inner portion of the posterior lobes (i.e., facing across the sinus) rounded, the edges almost touching in robust specimens. Leaf blade glossy dark green adaxially, dark red abaxially. Stipe of spadix strongly dorso-ventrally flattened, ca $8.5 \mathrm{~mm}$ long $\times$ $4.5 \mathrm{~mm}$ diam. . . . . . . . . . . . H. ardua P.C.Boyce \& S.Y.Wong

- Inner side of the posterior lobes (i.e, facing across the sinus) straight, their edges divergent. Leaf blade glossy medium green adaxially, somewhat paler abaxially. Stipe of spadix cylindrical, strongly dorso-ventrally flattened . . . . . . . . . 5

5. Leaf blade not or only very weakly quilted between the primary lateral veins. Stipe of spadix ca $3.5 \mathrm{~mm}$ long $\times 5 \mathrm{~mm}$ diam., short fusiform. Pistillate flower zone ca $2 \mathrm{~cm}$ long $\times$ ca $1 \mathrm{~cm}$ wide . . . . . . . . . H. josefii P.C.Boyce \& S.Y.Wong

- Leaf blade conspicuously quilted between the primary lateral veins. Stipe of spadix stipe 6-19 mm long $\times 5-7 \mathrm{~mm}$ width, weakly fusiform-cylindric. Pistillate zone 4.5-3.4 cm long $\times 9.5 \mathrm{~mm}$ wide. Matang (Sarawak), sandstones . . . . . . . . . .

H. debilicrista Y.C.Hoe

\section{Pollination observation of Homalomena debilicrista}

\section{Day One}

An inflorescence that had been monitored for several days prior was found at 17.30 with the lower spathe loosened slightly, and producing from the lower spathe a floral odour reminiscent of pungent lime and (faintly) of green tea. No insects were present.

\section{Day Two}

The lower spathe continued to loosen until 04.00 , by which time the gap between the margins of the lower spathe had widened to $3.4 \mathrm{~mm}$ and the spathe limb had began to open, initially with a centrally positioned gap $3.2 \mathrm{~cm}$ long $\times 3.3 \mathrm{~mm}$ wide, this then within a half hour opening to $6.3 \mathrm{~cm}$ long $\times 9.7 \mathrm{~mm}$ wide. The staminate portion of the spadix was by then visible, and the odour had intensified. Observation of the pistillate zone revealed the stigmas to be yellowish and wet, indicating pistillate anthesis.

The first visitor was a single Colocasiomyia fly on the staminate portion of the spadix. Within an hour the spathe limb was open to its fullest extent $(6.5 \mathrm{~cm}$ long $\times 2.6 \mathrm{~cm}$ wide), the spadix had elongated to exceed the spathe limb, with the tip of spathe limb remaining slightly convoluted. and the entire staminate zone could be observed. Floral odour was detectable ca $1 / 2 \mathrm{~m}$ from the plant. One individual of Chaloenus schawalleri approached to a distance of ca $15 \mathrm{~cm}$ but did not land.

Between 07.00-09.00, three individuals of Parastasia bimaculata arrived and were moving around inside the lower spathe. A solitary detached interpistillar staminode was observed adhering to the one of the legs of $P$. bimaculata, suggesting that staminodes were being dislodged by the beetles. Given the elasticity of the staminode stipe it is unlikely that the staminode was removed by accident and more probable that it had 
been bitten off by one of the Parastasia. While inside the spathe the beetles mated at the middle portion between the staminate and pistillate zones, and thereafter mostly remained inside the lower spathe. Further $C$. schawalleri arrived, landing on the interior of the spathe limb and from there crawling over the staminate zone and onto the pistillate zone, where they mated.

While the beetles were occupying the lower spathe, ca 10 individuals of a second taxon of Colocasiomyia arrived and were observed mainly on the inner spathe limb, as compared to very few on the staminate and pistillate zones. The Colocasiomyia were mating and deposited eggs at the inner spathe limb, staminate zone and few on the pistillate zone. The first taxon of Colocasiomyia did not utilize the inflorescence. During this later phase a single small dark orange Nitidulidae beetle visited the inner spathe limb and moved to the spathe limb constriction area, but no further.

By 13.00 damage was clearly visible to the staminate flower zone and inner spathe limb, caused by $C$. schawalleri.

By 18.30 the single Nitidulidae beetle had left the inflorescence, but P. bimaculata, C. schawalleri and the second Colocasiomyia remained.

\section{Day Three}

At 00.00 the staminate zone morphology changed to produce fissures between individual staminate flowers; at the same time the stigmas were observed to be dry and this was taken to mark the end of pistillate anthesis and the onset of the inter-anthesis phase. Further bite damage was observed on the spadix, and pale brown larvae of Colocasiomyia were present on the spathe interior. The Parastasia bimaculata mostly remained inside the chamber and continued to mate on the lower part of the staminate zone. Chaloenus schawalleri mostly remained inside the chamber and also mated there. Any Colocasiomyia flies present were mostly sucking moisture of unknown origin from the inner surface of the spathe limb, and were observed also mating there also.

By 02.00 the staminate zone began to further extend in length. After two hours many of the fissures between the staminate flowers began to fill with yellowish green resin that by 05.00 formed droplets on staminate surface. No pollen had been yet released. During this time the staminate zone length increased from $12.5 \mathrm{~cm}$ to $13 \mathrm{~cm}$.

At 05.45 pollen was released in dense white strands from the entire staminate zone, the pollen mixed with the resin to form sticky masses. This marked the end of the interanthesis phase and the start of staminate anthesis.

Following pollen release $C$. schawalleri and P. bimaculata activities initially remained the same, only an hour after pollen release did C. schawalleri move to the staminate zone, and were there observed feeding on the both the pollen and the synconnective tissue. The sticky pollen mosses adhered to the beetles, especially to the legs and mandibles. $\mathrm{Ca} 6$ C. schawalleri moved onto the inner spathe and remained there. By 0800 individuals of Parastasia bimaculata had moved to the staminate zone, and pollen was observed adhering to their legs, later there were observed to move back onto lower staminate zone and remain there. Neither species beetle left the inflorescence at this stage. By 1200, a single species of Staphylinidae visited the inner spathe 
but did not remain long time. By 1630, C. schawalleri left the inflorescence and approximately $1 / 3$ of the distal staminate zone was damaged by them.. However, $P$. $b i$ maculata still remained at the lower staminate zone, and a few Colocasiomyia flies were present on the inner spathe limb until by 18.30 the constriction between the lower spathe and spathe limb began to tighten. Only a few C. schawalleri and P. bimaculata remained inside the lower spathe, and a few Colocasiomyia flies were still present on the inner spathe limb. By this time approximately $1 / 3$ of the distal staminate zone had been damaged by $C$. schawalleri.

\section{Day Four}

By 02.00 the spathe limb had further tightened and the lower spathe changed from ovoid-ellipsoid to ellipsoid while much-restricting the entrance into the lower chamber. Both P.bimaculata and C. schawalleri left the lower spathe and were observed to move to the middle of the staminate zone. Colocasiomyia flies remained on the inner spathe limb. By 05.00 the uppermost part of the spathe limb tightened and curled downwards, while the margins of the lowermost part curled inwards. Parastasia bimaculata individuals climbed to the tip of the spadix and left the inflorescence, this correlated with the onset of pistillate anthesis of other inflorescences in the population. By 07.00 the lower half of the spathe limb was closed and only Colocasiomyia flies were present. The final closing of the spathe marked the end of the anthesis period, and within an hour no insect visitors were found.

\section{Conclusions}

The period of anthesis of $H$. debilicrista is ca $51 \frac{1}{2}$ hours. Comprising ca $19 \frac{1}{2}$ hours pistillate phase, ca 6 hours inter-anthesis phase, and a ca 26 hours staminate phase.

Key pollinator attraction and management features are: Odour production, food rewards (staminodes, pollen, and to a much lesser extent the synconnectives of staminate flowers), mating site and brood chamber (staminate and pistillate zone), and the size chamber formed by the lower spathe for shelter.

The pollinator for $H$. debilicrista are the beetles Parastasia bimaculata, and Chaloenus schawalleri. Both beetles harvested the inflorescence interpistillar staminodes, staminodes as a food reward (see also Momose et al., 1998; Gibernau, 2003; Kumano $\&$ Yamaoka, 2006) . The inflorescences also provided mating space (Gibernau, 2003) for both beetles. Inflorescences of Homalomena debilicrista produce a spicy scent (pungent lime). Kumano \& Yamaoka (2006) reported ruteline scarab beetles are attracted by spicy floral scents.

Initially Parastasia bimaculata, followed by Chaloenus schawalleri were strongly implicated as pollinators. Although both beetles remained in the inflorescences throughout most of the anthesis period, and both had pollen attached to their body parts, their departures from the inflorescence are different. The early morning departure of Parastasia bimaculata correlates with pistillate anthesis of another inflores- 
cence whereas Chaleonus schawelleri departs in the afternoon and with this there is a high possibility that any pollen carried will not find a an inflorescence at pistillate anthesis.

Colocasiomyia flies are very unlikely to be involved in pollen transfer. They almost exclusively visit only the inner spathe limb and very rarely the staminate zone and especially the pistillate zone. Colocasiomyia visited chiefly the inflorescence providing the mating site and brood site chamber. The structures functioning as a food reward are ignored by Colocasiomyia.

The short visitation period by Nitidulidae beetle and Staphylinidae indicate that they are unlikely to act as pollinators in H. debilicrista.

\section{Acknowledgements}

This study was funded by the Ministry of Higher Education, Malaysia by fundamental research grant scheme No. 600-RMI/ST/FRGS 5/3/Fst (14/2010) under Sarawak Forestry Department Research Permit No. NPW.907.4.4 (V)-77 \& Park Permit No. 34/2009. The collaboration and support of the Forest Department Sarawak and Sarawak Forestry Corporation are gratefully acknowledged.

\section{References}

Boyce, P.C. \& Wong, S.Y. 2008: Studies on Homalomeneae (Araceae) of Borneo I: Four new species and speculation on informal species groups in Sarawak. - Gard. Bull. Singapore 60: 1-29.

Gibernau, M. 2003: Pollinators and visitors of aroid inflorescences. — Aroideana 26: 73-91.

Kumano, Y. \& Yamaoka, R. 2006: Synchronization between temporal variation in heat generation, floral scents and pollinator arrival in the beetle-pollinated tropical Araceae, Homalomena propinqua. — Plant Spec. Biol. 21: 173-183.

Kumano-Nomura, Y. \& Yamaoka, R. 2009: Beetle visitations, and associations with quantitative variation of attractants in floral odors of Homalomena propinqua (Araceae). - J. Plant Res. 122(2): $183-192$.

Momose, K., T. Yumoto, T. Nagamitsu, M.Kato, H. Nagamasu, S. Sakai, R. D. Harrison, T. Itioka, A. A. Hamid \& T. Inoue. 1998: Pollination biology in a lowland dipterocarp forest in Sarawak, Malaysia. I. Characteristics of the plant-pollinator community in a lowland dipterocarp forest. - Am. J. Bot. 85: 1477-1501.

Mori, Y. \& Okada, H. 2001: Reproductive biology and pollen flow of a rheophytic aroid, Furtadoa sumatrensis (Araceae) in the Malesian wet tropics. - Plant Syst. Evol. 227: 37-47.

Ng, K.K., Sofiman O., Boyce, P.C. \& Wong, S.Y. in press: Studies on Homalomeneae (Araceae) of Borneo VIII: Delimitation of additional informal suprageneric taxa for Sundaic Homalomena. Webbia 66.

Okada, T. 1986: Estimation of the routes of synhospitalic distribution of the genus Drosophilella Duda (Diptera, Drosophilidae), with descriptions of three new species from Malaysia and Indonesia. — Proc. Jap. Soc. Syst. Zool. 33: 32-39.

Sultana, F., Toda, M.J., Yafuso, M., Lakim, M.B., Mohamed, M.B. \& Cuong, N.M. 2002: A new species-group of the genus Colocasiomyia de Meijere (Diptera: Drosophilidae), with descriptions of two new species from Eastern Malaysia and Vietnam. - Entomol. Sci. 5: 30-315.

Tung, L.S., Wong, S.Y. \& Boyce, P.C. 2010: Studies on Homalomeneae (Araceae) of Borneo VII: Homalomena giamensis L.S.Tung, S.Y.Wong \& P.C.Boyce (Araceae: Homalomeneae), a new species from Sarawak, Malaysian Borneo, with observations on its pollination. - Aroideana 23: 201-211. 
Wong, S.Y., Fasihuddin, B.A. \& Boyce, P.C. in press: Studies on Homalomeneae (Araceae) of Borneo III: The Helophytic Homalomena of Sunda. — Gard. Bull. Singapore 62.

Yafuso, M. \& Okada, T. 1990: Complicated routes of the synhospitalic pairs of the genus Colocasiomyia in Java, with description of two new species (Diptera, Drosophilidae). — Esakia 1: 137150 .

Addresses of the authors:

Hoe Yin Chen, Wong Sin Yeng, Department of Plant Science \& Environmental Ecology, Faculty of Resource Science \& Technology, Universiti Malaysia Sarawak, 94300 Kota Samarahan, Samarahan, Sarawak, Malaysia

Peter C. Boyce, Pusat Pengajian Sains Kajihayat [School of Biological Sciences], Universiti Sains Malaysia, 11800 USM, Pulau Pinang, Malaysia, corresponding author e-mail: phymatarum @ googlemail.com

Wong Mui Hung, Faculty of Applied Sciences, Universiti Teknologi MARA, 94300 Kota Samarahan, Samarahan, Sarawak

Margaret Chan Kit Yok, Faculty of Plantation and Agrotechnology, Universiti Teknologi MARA, 9430 Kota Samarahan, Samarahan, Sarawak 